\title{
Effect of Chicken Intestine Substitution on Chemical Quality of Nugget
}

\author{
Harapin Hafid, Nuraini, Dian Agustina, Fitrianingsih, Inderawati \\ ${ }^{1}$ Program Study of Animal Science, Faculty of Animal Science, Halu Oleo University \\ Jl. HEA Mokodompit Kampus Baru Anduonohu Kendari 93232 \\ *Corresponding author e-mail: harapinhafid14@gmail.com
}

\begin{abstract}
This research was aimed to study the chemical quality of the chicken nuggets substituted chicken intestine. There are eight levels of chicken intestine with chicken intestine consisting of $0 \%$ chicken intestine and $100 \%$ chicken meat, A1 consisting of $15 \%$ chicken intestine and $85 \%$ chicken meat, A2 consisting of $25 \%$ chicken intestine and $75 \%$ chicken meat, A3 consisting of $40 \%$ chicken intestine and $60 \%$ chicken meat, A4 consisting of $50 \%$ chicken intestine and $50 \%$ chicken meat, A5 consisting of $65 \%$ chicken intestine and $35 \%$ chicken meat, A6 consisting of $75 \%$ chicken intestine and $25 \%$ chicken meat, A7 consisting of $90 \%$ chicken intestine and $10 \%$ chicken meat, and A8 consisting of $100 \%$ chicken intestine and $0 \%$ chicken meat. Each treatment was repeated five times. The results showed that the water content and ash substituted chicken nuggets chicken intestines were not significantly different $(p>0.05)$. Intestine substitution into the chicken nuggets significant $(p<0.05)$ against the protein and fat content of chicken nuggets, where the highest protein content in treatment A8 (100\% chicken intestine) was $24.9 \%$ and the lowest in treatment A0 $(100 \%$ chicken meat) that is $11.33 \%$. The greater increase in the nugget chicken intestinal, the higher the protein content. Meanwhile nugget fat content tends to decrease as the percentage of the addition of chicken intestinal. The more the addition of substitution intestinal produce low-fat nugget. It was concluded that chicken intestine substitution may increase protein and decrease the fat content of chicken nuggets.

Keywords: nuggets, chicken meat, chicken intestines, chemical quality.
\end{abstract}

Abstrak. Penelitian ini bertujuan untuk mempelajari kualitas kimia nugget ayam yang disubstitusi usus ayam. Perlakuan subtitusi daging ayam dengan usus ayam ada delapan taraf yaitu A0 yang terdiri dari $0 \%$ usus ayam dan $100 \%$ daging ayam, A1 yang terdiri dari $15 \%$ usus ayam dan $85 \%$ daging ayam, A2 yang terdiri dari $25 \%$ usus ayam dan $75 \%$ daging ayam, A3 yang terdiri dari $40 \%$ usus ayam dan $60 \%$ daging ayam, A4 yang terdiri dari $50 \%$ usus ayam dan $50 \%$ daging ayam, A5 yang terdiri dari $65 \%$ usus ayam dan $35 \%$ daging ayam, A6 yang terdiri dari $75 \%$ usus ayam dan $25 \%$ daging ayam, A7 yang terdiri dari $90 \%$ usus ayam dan $10 \%$ daging ayam, dan A8 yang terdiri dari $100 \%$ usus ayam dan $0 \%$ daging ayam. Masing-masing perlakuan diulang lima kali. Hasil penelitian menunjukkan bahwa kadar air dan abu nugget ayam yang disubtitusi usus ayam tidak berbeda nyata ( $p>0.05)$, Kadar air nugget ayam pada penelitian ini adalah sebagai berikut A0 (99,8\%), A1 (99,8\%), A2 (99,8\%), A3 (99,8\%), A4 (99,8\%), A5(99,9\%), A6(99,9\%), A7 (99,7\%), dan A8 (99,8\%). Kadar abu pada A0 $(2,61 \%)$, A1 (1,61\%), A2 (2,90\%), A3 (1,80\%), A4 (2,23\%), A5 (2,84\%), A6 (2,62\%), A7 (2,39\%), dan A8 $(2,26 \%)$. Subtitusi usus ke dalam nugget ayam berpengaruh nyata $(p<0,05)$ terhadap kadar protein dan lemak nugget ayam, dimana kadar protein tertinggi pada perlakuan A8 (100\% usus ayam) yaitu $24,9 \%$ dan terendah pada perlakuan A0 (100\% daging ayam) yaitu $11,33 \%$. Semakin besar penambahan usus ayam dalam nugget, kadar protein semakin tinggi. Sementara itu kadar lemak nugget cenderung menurun seiring besarnya persentase penambahan usus ayam. Semakin banyak penambahan subtitusi usus menghasilkan produk nugget yang rendah lemak. Dapat disimpulkan bahwa substitusi usus ayam dapat meningkatkan protein dan menurunkan kandungan lemak nugget ayam.

Kata kunci: nugget, daging ayam, usus ayam, kualitas kimia

\section{Introduction}

Producing quality livestock products with high nutritional value and low cost is the main goal of livestock processing. This requires considerable creativity by designing an economical material formulation (Hafid \& Syam, 2007). The use of livestock waste or byproducts such as intestines in the manufacture of processed including the efforts that need to be considered.

Chicken intestine is a byproduct chicken cutting. Intestine has relatively low commercial value, but have a complex nutrient content. The protein content of chicken intestine was 22, $93 \%$, fat 5,6\%, and ash 3,44\% (Baihaki et al., 
2010). So far the utilization of chicken intestines is still limited. Chicken intestines used as catfish feed and raw materials for chips satay intestine or bowel, particularly in Java. In Southeast Sulawesi, people are still foreign to processed foods made from the intestine. Most chicken intestines are discarded as waste that is not useful. If viewed from the nutritional content, chicken intestine is a potential food product of animal origin (Hafid et al., 2017)

Nugget is one of the food products of animal origin. Nugget is a form of spiced ground beef product, and then covered by gluten flour (batter), breadcrumbs giving (breading) and fried half-baked and then frozen to preserve quality during storage. Main raw material of nuggets comes from chicken, beef, mutton, and marine animals such as fish and shrimp (Tasse, et al., 2015).

This research aims to study the chemical quality of the chicken nuggets substituted chicken intestine. Expected to be a reference utilization of slaughterhouse waste in the form of intestinal hardly worth the price and can be a source of environmental pollution form of stench to process them into nutritious food products.

\section{Materials and Methods}

The material used in this study were chicken nuggets with the main ingredient of meat and intestines of broilers obtained from the vendors in Anduonohu market at Kendari. Additional ingredients such as tapioca, breadfruit flour, and spices (garlic, pepper powder, salt, nutmeg flavoring powder, skim milk, flour crumb, and eggs).

Making the nugget follow the steps being taken by the Laksono et al. (2012) which has been modified. Chicken and chicken intestines (as per treatment formulation) are $300 \mathrm{~g}$ ground, then added ice and salt flakes, then added sugar, pepper, garlic, skim milk, corn oil and tapioca flour. All the ingredients are stirred into a homogeneous dough. The nuggets of dough in a baking dish molded aluminum, and covered by using plastic then steamed. Steaming dough made until the internal temperature reaches 60 to $70^{\circ} \mathrm{C}$ for approximately 30 minutes, after steaming, the dough nuggets that have cooled to room temperature and then inserted into the refrigerator for $\mathbf{3 0}$ minutes. The dough that has been dense is called half-baked dough. The dough is then cut into pieces of approximately 4 $x 4 \mathrm{~cm}$ with a thickness of one $\mathrm{cm}$, then dough smeared with eggs and smeared again with bread. The initial frying using oil was submerged for 30 seconds at $200^{\circ}$ C. Nugget packed in plastic and stored in a freezer and then performed the final frying ie nuggets fried for four minutes at $200{ }^{\circ}$ C. Nugget making process shown in Figure 1

Table 1. Chicken Nugget Ingredients substituted with Chicken Intestine

\begin{tabular}{llllllllll}
\hline Ingredients (\%) & \multicolumn{1}{c}{ Treatment } \\
\cline { 2 - 11 } & A0 & A1 & A2 & A3 & A4 & A5 & A6 & A7 & A8 \\
\hline Chicken meat & 100 & 85 & 75 & 60 & 50 & 35 & 25 & 10 & 0 \\
Chicken intestine & 0 & 15 & 25 & 40 & 50 & 65 & 75 & 90 & 100 \\
Tapioca flour & 10 & 10 & 10 & 10 & 10 & 10 & 10 & 10 & 10 \\
Garlic & 3 & 3 & 3 & 3 & 3 & 3 & 3 & 3 & 3 \\
Pepper powder & 2 & 2 & 2 & 2 & 2 & 2 & 2 & 2 & 2 \\
Salt & 2.5 & 2.5 & 2.5 & 2.5 & 2.5 & 2.5 & 2.5 & 2.5 & 2.5 \\
Nutmeg powder & 0.25 & 0.25 & 0.25 & 0.25 & 0.25 & 0.25 & 0.25 & 0.25 & 0.25 \\
Flavoring & 1 & 1 & 1 & 1 & 1 & 1 & 1 & 1 & 1 \\
Sugar & 1 & 1 & 1 & 1 & 1 & 1 & 1 & 1 & 1 \\
Skimmed milk powder & 5 & 5 & 5 & 5 & 5 & 5 & 5 & 5 & 5 \\
\hline
\end{tabular}




\section{Meat Quality Test}

\section{Water Content (KA) (AOAC, 2005)}

First the empty bowl is dried in the oven at $105^{\circ} \mathrm{C}$ for 15 minutes and cooled in the desiccator, then weighed. A total of $10 \mathrm{~g}$ sample and inserted in the cup which had been weighed and then dried in the oven at $105^{\circ} \mathrm{C}$ for 12 hours. The plate containing the dried sample is subsequently transferred into the desiccator, cooled and then weighed. Drying is done until a constant weight is obtained. Drying is done until a constant weight is obtained. The percentage of moisture content is calculated as follows:

Water content $(\%)=\frac{\text { sample weight }(\text { start })-\text { sample weight }(\text { end })}{\text { sample weight }(\text { end })} \times 100 \%$

\section{Ash Content (AOAC, 2005)}

Sample nuggets were used to test the water content is as much as $10 \mathrm{~g}$ inserted into the porcelain dish, then put into an electric furnace at a temperature of $400-600^{\circ} \mathrm{C}$. After the sample whitish sample is lifted then moved into a desiccator and cooled and weighed. Ash content can be calculated by the way. Ash content formula as follows:

Ash content $(\%)=\frac{\text { weight of ash }}{\text { fresh weight }} \times 100 \%$

\section{Protein (AOAC, 2005)}

Measurement of protein levels was calculated using Kjeldahl with the work that is, used as a sample of $10 \mathrm{~g}$ put in a $100 \mathrm{ml}$ Kjeldahl flask, then added $2 \mathrm{~g}_{\text {of }} \mathrm{K}_{2} \mathrm{SO}_{4}, 20 \mathrm{ml}$ of $\mathrm{H}_{2} \mathrm{SO}_{4}$ concentrated and boiling stones. After that for 30 minutes done distruction until obtained light green liquid (clear).

Distruction results plus distilled water $10 \mathrm{ml}$, then shaken until homogeneous, then $20 \mathrm{ml}$ of the solution was added $\mathrm{NaOH}$ concentrated 20 $\mathrm{ml}$ and indicators pp 3 drops then distilled by holding erlenmeyer flask $125 \mathrm{ml}$ containing
$\mathrm{H}_{3} \mathrm{BO}_{3} 3 \%$ of $20 \mathrm{ml}$, and metal indicator red and blue metal each 2 drops. After distillation with $0.1 \mathrm{~N} \mathrm{HCl}$ until it changes color to light purple. For blank solution done in the same way but without using the sample. Measurement of protein content was done by using kjeldalh method of nitrogen content calculated by the formula:

$$
\text { Nitrogen }(\%)=\frac{(\mathrm{HCL}-\text { blanko }) \times \text { N HCL x } 14.007}{\text { mg sample }} \times 100 \%
$$

\section{Fat Levels (AOAC, 2005)}

The method used for fat content is the soxlet method. The sample is weighed as much as $1 \mathrm{~g}$ later weighed wrapped with fat-free dry paper and put in the oven with a temperature of $150^{\circ} \mathrm{C}$ for one night. The dried samples taken were weighed in a still warm state, then incorporated into a soxhlet extraction tool. The reservoir was filled with chlorophyroid and methanol with a 2: 1 ratio of half the contents of the reservoir. The soxhlet extraction tool also filled the same solution up to half the volume. After that it was extracted for about 8 hours, then the sample was taken and dried in the oven for 24 hours. After dry the sample is weighed in the heat. The method used for fat content is the soxlet method. Percentage of fat content is calculated as follows:

Fat content $(\%)=\frac{\text { sample weight }(\text { start })-\text { sample weight }(\text { end })}{\text { sample weight }(\text { end })} \times 100 \%$

\section{Results and Discussions}

Chemical quality showed that the moisture content and ash throughout each treatment showed no significant difference $(p>0.05)$, while the crude protein and fat indicates significantly different $(P<0.05)$. Chemical quality chicken nuggets with chicken intestines substitution during the study are presented in Table 2. 


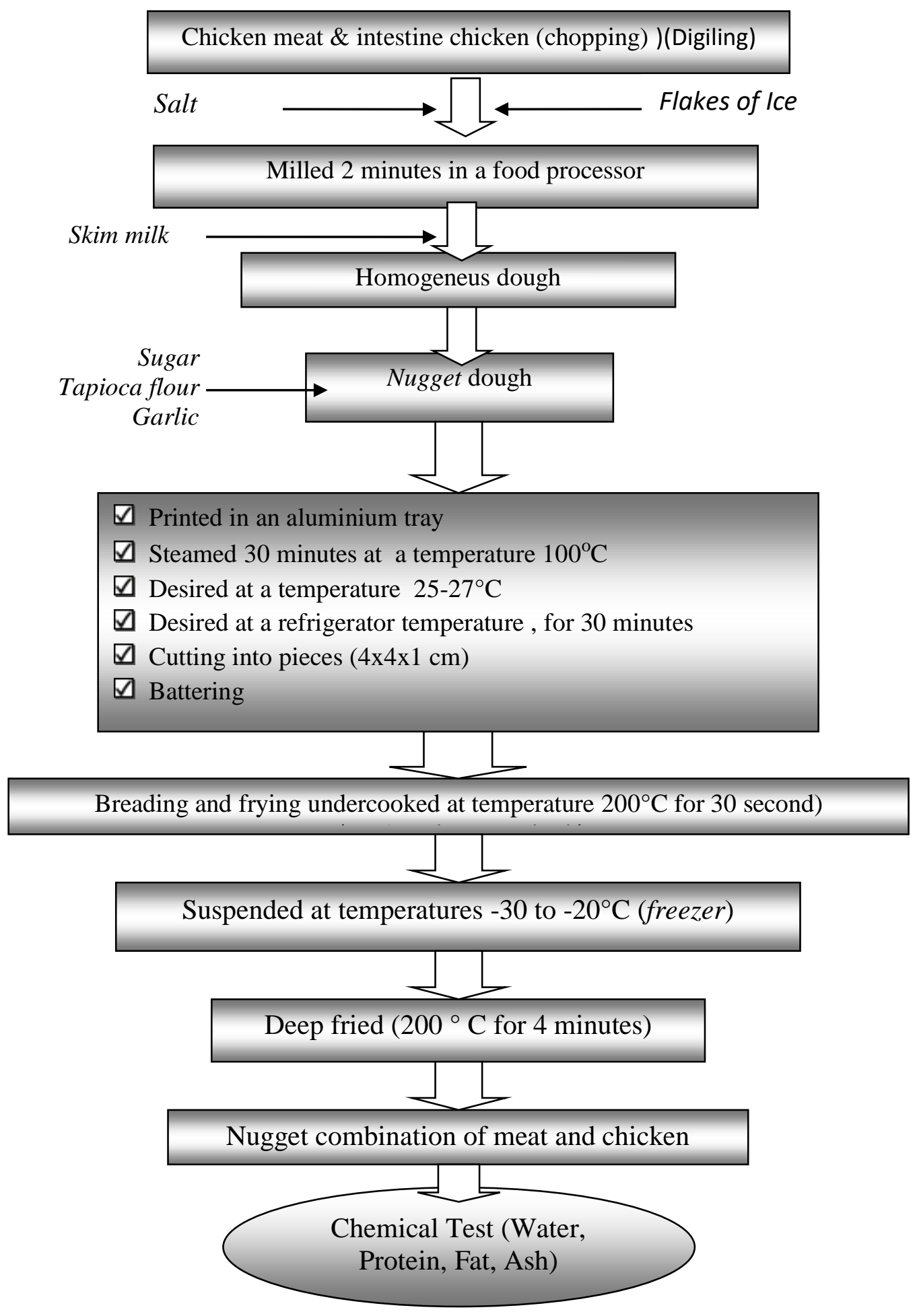

Figure 1. Nugget Processing Scheme 
Table 2. Quality Chicken nuggets with chicken intestine substitution

\begin{tabular}{|c|c|c|c|c|c|c|c|c|c|c|}
\hline \multirow{2}{*}{\multicolumn{2}{|c|}{ Quality Chemistry }} & \multicolumn{9}{|c|}{ Treatment } \\
\hline & & $\mathrm{A} 0$ & A1 & $\mathrm{A} 2$ & A3 & A4 & A5 & A6 & A7 & A8 \\
\hline Water (\%) & & $99.8^{a}$ & $99.8^{a}$ & $99.8^{a}$ & $99.8^{a}$ & $99.8^{a}$ & $99.9^{a}$ & $99.9^{a}$ & $99.7^{a}$ & $99.8^{a}$ \\
\hline Crude protein $(\%$ & & $11.33^{\mathrm{a}}$ & $13.75^{\mathrm{b}}$ & $14.58^{b}$ & $15.75^{c}$ & $17.58^{d}$ & $18.58^{d}$ & $19.83^{e}$ & $22.83^{f}$ & $24.95^{\mathrm{g}}$ \\
\hline Fat (\%) & & $23.93^{\mathrm{g}}$ & $21.85^{f}$ & $20.56^{f}$ & $19.09^{e}$ & $18,14^{\text {de }}$ & $17.03^{\mathrm{cd}}$ & $15.69^{c}$ & $14.11^{b}$ & $11.00^{\mathrm{a}}$ \\
\hline Ash (\%) & & $2.61^{a}$ & $1.84^{\mathrm{a}}$ & $2.90^{\mathrm{a}}$ & $1.80^{\mathrm{a}}$ & $2: 23^{a}$ & $2.84^{\mathrm{a}}$ & $2.62^{\mathrm{a}}$ & $2: 39^{a}$ & $2: 26^{a}$ \\
\hline $\begin{array}{r}\text { Th } \\
\text { A } \\
\text { A } \\
\text { A } \\
\text { A } \\
\text { A } \\
\text { A } \\
\text { A } \\
\text { A } \\
\text { A }\end{array}$ & $\begin{array}{l}\text { he nu } \\
A 0= \\
A 1= \\
A 2= \\
A 3= \\
A 4= \\
A 5= \\
A 6= \\
A 7= \\
A 8=\end{array}$ & $\begin{array}{l}\text { oers follo } \\
\text { chicken } \\
\% \text { chicke } \\
\% \text { chicke } \\
\% \text { chicke } \\
\% \text { chicke } \\
\% \text { chicke } \\
\% \text { chicke } \\
\% \text { chicke } \\
\text { 0\% chick }\end{array}$ & $\begin{array}{l}\text { ved by d } \\
\text { ntestine } \\
\text { intestine } \\
\text { intestine } \\
\text { intestine } \\
\text { intestine } \\
\text { intestine } \\
\text { intestine } \\
\text { intestine } \\
n \text { intestir }\end{array}$ & $\begin{array}{l}\text { fferent I } \\
+100 \% \\
+85 \% \\
+75 \% \\
+60 \% \\
+50 \% \\
+35 \% \\
+25 \% \\
+10 \% \\
e+0 \%\end{array}$ & $\begin{array}{l}\text { tters on } \\
\text { hicken } \mathrm{m} \\
\text { hicken } \mathrm{m} \\
\text { hicken } \mathrm{m} \\
\text { hicken } \mathrm{m} \\
\text { hicken } \mathrm{m} \\
\text { hicken } \mathrm{m} \\
\text { hicken } \mathrm{m} \\
\text { hicken } \mathrm{m} \\
\text { hicken } \mathrm{m}\end{array}$ & $\begin{array}{l}\text { the same } \\
\text { eat } \\
\text { eat } \\
\text { eat } \\
\text { eat } \\
\text { eat } \\
\text { eat } \\
\text { eat } \\
\text { eat } \\
\text { eat }\end{array}$ & sho & mark & iffer & $(P<0.0$ \\
\hline
\end{tabular}

\section{Water content}

The water content is a very important parameter in determining the quality of the nugget, Table 2 it can be seen that the substitution of chicken intestine with different percentages are not significantly different ( $p>0.05)$ on the water content. Water content of chicken nuggets in this study is very high. According to the National Standard of Indonesia, nuggets maximum water content is $60 \%$ (BSN, 2002; Laksono et al., 2012).

The high possibility is caused by a long enough intestinal griding process in which the elastic and tough intestines must first be chopped and then milled using ice cubes. The composition of the nugget is expected to affect water levels nugget produced. Setaningrum (2013) obtain seaweed nuggets water content ranging from $73,10 \%$ - 77,72\%. Meanwhile, according to Abubakar (2013) commercial nugget content water is $51,82 \%$. The main factor of water content of the product is the main raw material, water added during cooking and water liberation during cooking, other factor influencing the water content is frying process (Winarno, 1997). Meanwhile, by Soeparno (2009) high water levels can be used as an indication of good water-binding power.

\section{Protein levels}

The results showed intestinal waste substitution of chicken in the chicken nuggets significant $\quad(p<0,05)$ the protein content of chicken nuggets. The highest protein content in treatment A8 (100\% chicken intestine) is $24.9 \%$ and the lowest in treatment A0 (100\% chicken), i.e. $11.33 \%$. The larger the addition of chicken intestinal waste into nuggets, protein content tends to be higher.

Chicken nuggets with the addition of a variety of different types of materials, tend to produce different protein levels. Chicken nuggets with the addition of $25 \%$ suweg flour as filler has a protein content of $18.61 \%$ (Gumilar et al., 2011). Meanwhile rabbit nuggets plus soybean flour has a protein content between 17, 43\% to 19.93\% (Afrisanti, 2010).

According SNI 01-6683-2002 about chicken nuggets, nugget protein content requirement of at least $12 \%$ (National Standardization Agency, 2002). The protein content in the product nuggets are affected by the type and protein content of raw materials and supplies used. The use of substitute materials such as chicken intestinal waste is believed to be able 
to contribute to elevated levels of protein in the product nuggets. As is known that chicken intestine contains a high enough protein. Chicken intestinal protein content reaches 22, 93 (Baihaki, et al., 2010).

It could be argued that the substitution of chicken intestinal waste have a positive influence on the protein content of the product nuggets. Protein is a nutrient that is essential for the body because it serves as a fuel, a substance the body builders and regulators (Winarno, 1997).

\section{Fat level}

Fats, proteins and carbohydrates are the building blocks of living cell structures and their derivatives. In food, the fat is used as the medium of heat in the frying process (Chen and Chen, 2003), in addition to the fat also acts as a flavoring savory as well as improve the texture and taste of food.

Low levels of nugget fat caused by the intestinal material used have a low-fat content than chicken meat results of the study (Table 2). Nugget fat content tends to decrease as the percentage of the addition of chicken intestinal waste. Nugget fat content ranging from 11.00 to 23.93. Fat content nugget in this study is much lower when compared to the commercial nugget that is $34,48 \%\left(\begin{array}{ll}\% & d b\end{array}\right)$ (Abubakar et al., 2013).

The type and nutrient content of raw material in the manufacture of influencing fat nugget nuggets produced products. According to the United States Department of Agriculture (2011), the total fat content of chicken meat is $11 \%$, while the fat content in the intestine only $5,60 \%$ (Baihaki et al, 2010). So the more the percentage of substitution of the intestine in the nugget, which is followed by the least percentage of chicken meat, will produce lowfat nugget.

Meat and cooking methods also affect the fat content of the final product. The meat portion used in this study is breastless meat and thighs without skin, so it tends to produce a low-fat nuggets product. Coupled with the substitution of the poor chicken intestinal waste fat content, so the higher the percentage of waste substitution intestine, fat content tend to show a significant decline. Nugget is a food product that is passed through the frying process. Fryers generally will increase the fat content of a food product. However, in this study tend not affect the frying fat nugget. It is caused by a short frying time of 30 seconds with a high temperature $\left(200^{\circ} \mathrm{C}\right)$.

\section{Ash content}

In addition to organic matter and water, chicken nuggets also contain inorganic (mineral). In Table 2. it can be seen that with the substitution of chicken intestine with different percentages, show the results of which were not significantly different $(p>0.05)$ on the ash content of chicken nuggets. The ash content ranging from 1, $61-2,84 \%$. The ash content of products nugget in this study was lower than the ash content of duck meat nuggets that ranged from 3, 47 to $4.12 \%$ (Abubakar et al., 2013). While the ash content nugget in this study do not differ much with rabbit nuggets ash content with the addition of soybean flour ranged between $216-2.14 \%$ (Afrisanti, 2010). Rabbit nuggets without the addition of soybean flour contains a higher ash content, namely $6,39 \%$ up to $5.38 \%$ (Nurcahyanti, 2009).

In addition to coming from primary raw, ash content in chicken nuggets can also be derived from binders, fillers and flavorings (Nutrition Directorate of the $\mathrm{MOH}, 1995)$, the ash content of a product also has a relationship with the mineral content results in the material. The main raw material in this study were chicken meat and chicken intestinal waste. The ash content of chicken intestine is 3,44\%(Baihaki et al. , 2010), while the mineral content of chicken meat is $0.72 \%$ 
(Soeparno, 2009). In addition to coming from the raw materials, the ash content of a product is also influenced by the treatment process. Sundari et al. (2015) states that food that is experiencing the cooking process can be decreased and the increase ash content from fresh material. Substitution of chicken intestinal waste into nuggets does not affect the ash content in the product nuggets.

\section{Conclusions}

It can be concluded that chicken intestine substitution can increase protein and decrease the fat content of chicken nuggets. Nugget product with composition $50 \%$ chicken intestine and $50 \%$ chicken meat (A4) has water content $99,8 \%, 17,58 \%$, protein, $18,14 \%$ fat and ash. $2.23 \%$ preferred by panelists.

\section{Acknowledgment}

Thanks and appreciation to the Directorate General for Research and Development, Ministry of Research, Technology and Higher Education who has funded this research with no. SP. DIPA-042.06.1.401516 / 2017.

\section{References}

Afrisanti DW. 2010. Kualitas Kimia dan Organoleptik Nugget Daging Kelinci dengan Penambahan Tepung Tempe. Skripsi. Universitas Sebelas Maret Surakarta. Surakarta

AOAC. 2005. Official Method of Analysis. Association of Official Analytical Chemist, Washington DC.

Badan Standarisasi Nasional (BSN). 2000. SNI Syarat Mutu Bahan Baku Surimi (SNI 19-1705-2000). Badan Standarisasi Nasional, Jakarta.

Badan Standardisasi Nasional. 2002. Nugget Ayam. SNI 01-6683. Badan Standardisasi Nasional, Jakarta.
Baihaki M, Ramadhanti, Resta, NK Sari dan IM Areopagus. 2010. Pemanfaatan Usus Ayam sebagai Upaya Pemulihan Terhadap Akibat Flu Burung. Politeknik Negeri Lampung, Lampung.

Chen YC dan BH Chen. 2003. Determination of polycyclic aromatic hydrocarbons in fumes from fried chicken legs. J. Agric. Food Chem.51(14): $4162-4167$.

Direktorat Gizi Depkes RI. 1995. Daftar Komposisi Bahan Makanan. Bharata karya Aksara, Jakarta.

Hafid, H., dan A Syam. 2007. Pengaruh aging dan lokasi otot terhadap kualitas organoleptik daging sapi Buletin Peternakan.31(4) : 209-216.

Hafid H., Nuraini, D. Agustina, Fitrianingsih, dan Inderawati. 2017. Kualitas organoleptik nugget yang disubstitusi usus ayam. Prosiding Seminar Nasional Industri Peternakan I. Fakultas Peternakan IPB. Bogor. P. 72-77.

Laksono, M.A., V.P. Bintoro dan S. Mulyani. 2012. Daya ikat air, kadar air, dan protein nugget ayam yang disubstitusi jamur tiram putih (Pleurotus astreatus). Animal Agriculture Journal. 1 (1) : 685 $-696$.

Nurcahyanti D. 2009. Pengaruh Ratio Daging dan Filler Tepung Tapioka terhadap Kualitas Fisik dan Sensoris Nugget Kelinci. Skripsi, Universitas Gadjah Mada, Yogyakarta.

Setyaningrum dan Sukesi. 2013. Preparasi penentuan ca, na, dan $\mathrm{k}$ dalam nugget ayamrumput laut (eucheuma cottonii). Jurnal Sains dan Seni Pomits. Vol. 2, No. 1, (2013) 1-4.

Soeparno. 2009. Ilmu dan Teknologi Daging, Gadjah Mada University Press, Yogyakarta.

Sundari D, Almasyhuri dan A. Lamid. 2015. Pengaruh proses pemasakan terhadap Komposisi zat gizi bahan pangan sumber Protein. Media Litbangkes, Vol. 25 No. 4, Desember 2015, 235 242.

Tasse AM, I Nurhinayah dan H. Hafid. 2015. Nugget Ayam Afkir Tersubstitusi Otak Sapi Komposisi Kimia dan Organoleptik. Prosiding Seminar Nasional Swasembada Pangan. Perhepi Universitas Halu Oleo, Kendari. P. 183-186.

United States Department of Agriculture. 2011. Chicken \& Turkey Nutrition Fact. Food Safety and Inspection Service.

Winarno, F.G. 1997. Kimia Pangan dan Gizi. PT. Gramedia Pustaka Utama, Jakarta. 